\title{
レポート
}

\section{原子力事故後の家屋内における さまざまな部材の拭き取り効率調査}

$\begin{array}{rrrr}\text { 森愛 理*1,\#, 石﨑 梓*1, 普天間 } & \text { 章*1, 田辺 務*2, } \\ & \text { 和田 孝雄*3, 加 藤 } & \text { 貢*4, 宗像 } & \text { 雅広*1 }\end{array}$

(2018 年 9 月 11 日受付)

(2018 年 11 月 19 日採択)

\section{Investigation of Removal Factors of Various Materials inside Houses after Nuclear Power Station Accident}

Airi Mori, ${ }^{* 1, \#}$ Azusa Ishizaki, ${ }^{* 1}$ Akira Futemma, ${ }^{* 1}$ Tsutomu Tanabe, ${ }^{* 2}$ Takao WADA, ${ }^{* 3}$ Mitsugu Kato*4 and Masahiro MunaKata ${ }^{* 1}$

\begin{abstract}
Large quantities of radionuclides were released as a result of Fukushima Daiichi Nuclear Power Station accident. It is known that these radionuclides contaminated inside houses as well as outdoor environment. Considering the radiation protection of residents after a nuclear power station accident, it is important to know the influence of radionuclides inside houses to radiation dose to residents. In this study, we investigated removal factors and fractions of fixed contamination of various materials inside houses in Okuma Town, Futaba Town, and Namie Town to assess the contamination level inside house appropriately. Nine kinds of materials: fibers, woods (smooth), woods (rough), glasses, concretes (smooth), concretes (rough), plastics, PVCs and metals, were used in examinations. The lowest and the highest removal factors were $23 \% \pm 16 \%$ of woods (rough) and $79 \% \pm 7.7 \%$ of glasses, respectively. Removal factors of all materials were higher than $10 \%$ which is recommended by Japanese Industrial Standard. The negative correlation was found between removal factors and fractions of fixed contamination. Using this correlation, the decontamination efficiency, which means the ratio of the activity removed from the surface by one smear sample to the activity of the total surface activity, was proposed. The air dose rate from the contamination inside house was calculated using obtained decontamination efficiencies and removal factor of $10 \%$. In the case using the removal factor of $10 \%$, the air dose rate derived by indoor contamination was approximately 2 times higher than the case using obtained decontamination efficiencies. We found that the air dose rate derived by indoor contamination was much lower than the air dose rate outside house, and the influence of indoor contamination on the external exposure was small.
\end{abstract}

KEY WORDS: removal factor, smear method, Fukushima Daiichi Nuclear Power Station accident, evacuation area, inside house, air dose rate.

\section{I 緒 論}

東京電力福島第一原子力発電所（FDNPS）事故によ り放射性物質が環境中へと放出され，事故の影響を受け
た地域の住民は避難を余儀なくされた。事故後 6 年が経 過する間に屋外の空間線量率の変化に伴って避難指示 区域の再編が行われ，2017 年 4 月 1 日には大熊町, 双 葉町, 及び州還困難区域を除くすべての地域の避難指
*1 (国研) 日本原子力研究開発機構安全研究センター; 茨城県那珂 郡東海村白方白根 2-4（产 319-1195）

Nuclear Safety Research Center, Japan Atomic Energy Agency; 2-4 Sirakata-Sirane, Tokai-mura, Naka-gun, Ibaraki 319-1195, Japan.

*2（国研）日本原子力研究開発機構福島環境安全センター；福 島県田村郡三春町深作 10-2（产 963-7700）

Fukushima Environmental Safety Center, Japan Atomic Energy Agency; 10-2 Fukasaku, Miharu-machi, Fukushima 963-7700, Japan.

*3 (国研) 日本原子力研究開発機構核燃料サイクル工学研究所 保安管理部；茨城県那珂郡東海村村松 4-33（ ₹ 319-1194）
Safety Administration Department, Nuclear Fuel Cycle Engineering Laboratories, Japan Atomic Energy Agency; 4-33 Muramatsu, Tokai-mura, Naka-gun, Ibaraki 319-1194, Japan.

*4 (国研) 日本原子力研究開発機構環境技術開発センター; 茨 城県東茨城郡大洗町成田町 4002（ ₹ 311-1393）

Waste Management and Decommissioning Technology Development Center, Japan Atomic Energy Agency; 4002 Narita-cho, Oaraimachi, Higashiibaraki-gun, Ibaraki 311-1393, Japan.

\# Corresponding author; E-mail: A.Mori@iaea.org 
示が解除された1)。2012 年 4 月 1 日以降, 避難指示区域 は年間の積算線量の推定值を基準に定められ, $20 \mathrm{mSv} /$ y 以下になることが確実な地域を避難指示解除準備区 域, $20 \mathrm{mSv} / \mathrm{y}$ 超えるおそれがある地域を居住制限区域, $50 \mathrm{mSv} / \mathrm{y}$ 超えていて, 5 年後も $20 \mathrm{mSv} / \mathrm{y}$ を回らな いおそれがある地域を帰還困難区域としている2)。年間 の積算線量は屋外の空間線量率の測定値を利用して計算 されており ${ }^{3)}$, 屋内の污染は無いものと仮定されている が，近年の調查により，FDNPS 周辺では放射性物質は 屋外だけでなく家屋内にも沈着していることが分かって きた文。そのため, 事故後における住民の放射線防護を 考えるうえで, 家屋内に沈着した污染に由来する外部被 ばく線量が全体の外部被ばく線量にどの程度影響するか を把握しておくことは重要である。

家屋内の污染に由来する線量当量率は, 屋外の污染に 由来する放射線の影響があるため $\mathrm{NaI} （ \mathrm{Tl}$ ） シンチレー ション式サーベイメータ等により測定することはきわめ て困難である。よって屋内に污染がどの程度存在するの か, つまり, 表面污染密度がどの程度であるかを測定す る必要がある。表面污染密度の測定には主に直接法と間 接法の 2 通りの方法がある ${ }^{5)}$ 。直接法とは, GM 管式サー ベイメー夕等で物体表面の污染の程度を直接測定する方 法である。間接法とは, 污染を拭き取ったスミアろ紙 等を $\mathrm{GM}$ 管式サーベイメー夕等で測定する方法である。 これらの手法は原子力施設等の管理区域において污染を 検出することを想定して開発されており, 家屋内の污染 状況の把握に適用するためにはいずれの手法にも以下の ような課題がある。

直接法においては測定対象以外の周辺污染による測定 值の不確実性が課題となる。FDNPS 周辺の地域では常 に周囲に污染が存在する状態となっているため, 測定値 はサーベイメータの検出空以外から入射する放射線の影 響を受ける。また, 測定対象面の背面部等に污染がある 場合はその污染の影響を受ける。例えば, 家屋内の壁表 面に付着した污染を測定する場合は，外壁面に付着した 污染及び屋外に存在する污染に由来する放射線が測定值 に影響を及ぼす。テーブルの表面污染を測定する場合は， テーブルの下の床及びテーブル天板の裏側に存在する污 染に由来する放射線が測定值に影響を及ぼす。このよう に, 測定対象以外の箇所からの放射線の影響を受けるよ うな場所の測定には直接法は不向きである。

間接法では，スミアろ紙等により污染がどの程度拭き 取れたかを示す拭き取り効率を求める必要がある。拭き 取り効率に実験的データがない場合は, 部材の種類にか
かわらず拭き取り効率を $10 \%$ とすることが JIS により 定められている5゙。しかし拭き取り効率は部材により大 きく異なることが知られている。これまで原子力施設等 においては施設内の部材を構成するコンクリート類, 塩 化ビニル類, 金属類等について拭き取り効率を求める実 験が行われてきた ${ }^{(-9)}$ が，いずれも拭き取り効率 $10 \%$ よ りも大きい值を示しており，拭き取り効率を $10 \%$ とす ると表面污染密度を数倍程度過大評価する可能性があ る。また家屋内装部材の拭き取り効率, 加えて FDNPS 事故の影響で污染された実際の家屋における拭き取り効 率に関する調査はほとんど例がない。さらに, 間接法に より測定できるのは, 物質の全表面污染のうち, 万紙等 により拭き取れる污染，つまり遊離性表面污染のみであ り，ろ紙等により拭き取れない污染，つまり固定性表面 污染は測定することができない。被ばく線量評価の観点 から重要となるのは全表面污染であるため, 拭き取り効 率の值だけではなく, 固定性表面污染の割合がどの程度 であるかも知る必要がある。

以上の課題を踏まえ本研究では, 家屋内污染の適切な 評価によって家屋内污染に由来する被ばく線量を合理的 に評価するため, 大熊町, 双葉町, 及び浪江町の実家屋 に扔いてさまざまな部材の拭き取り効率等を調查し, 污 染の評価手法を検討した。

\section{II 実験}

本研究では家屋内の同一箇所の污染面において, GM 管式サーベイメー夕（日立アロカメディカル（株）, TGS-146B）を用いた直接法による表面污染の測定と, スミアろ紙（ADVANTEC，杓子型，直径 $25 \mathrm{~mm}$ ）を用 いた拭き取り試験を行い，拭き取り効率及び固定性表面 污染の割合を求めた。

\section{1. 測定対象}

実験は，大熊町の家屋 3 軒（FDNPS から $1.9 \mathrm{~km}$ 北西， $3.7 \mathrm{~km}$ 西, 及び $5.5 \mathrm{~km}$ 南西), 双葉町の家屋 1 軒 (FDNPS から $3.6 \mathrm{~km}$ 北西), 及び浪江町の家屋 1 軒 (FDNPS か ら $12 \mathrm{~km}$ 北西）で行った。Fig. 1 に調查を行った家屋の 場所を示す。測定対象とした部材は, 瀻維類, 木材類 などの害際の家屋で用いられている部材である。Table 1 に測定対象の分類と部材の例を示す。2a. 木材類（平 滑)は木材の表面に塗装等の処理が施されているものを, 2b. 木材類（凹凸）は表面が未処理のものを指す。測定 対象の選定基準として, 一般的な家庭にある材質で, か つ対象面の上部にテーブル等の被覆物がないこと, 及び 


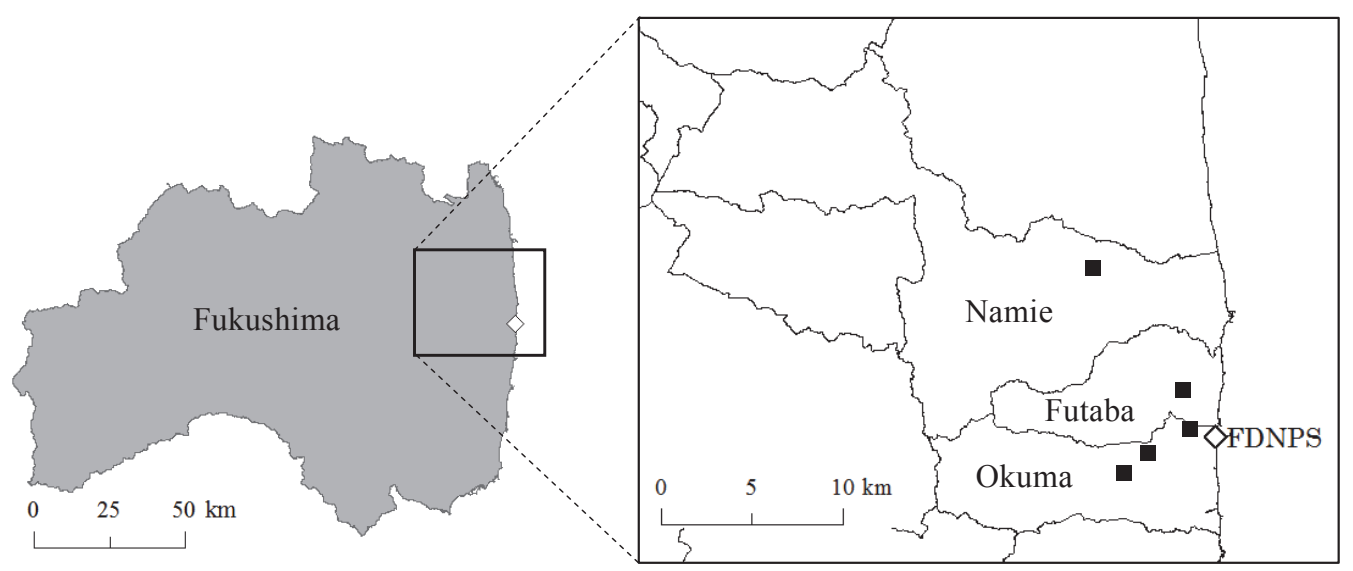

Fig. 1 Location of houses in evacuation area. Black squares indicate houses, and white diamond indicates FDNPS.

Table 1 Materials used in examinations.

\begin{tabular}{lll}
\hline \multicolumn{1}{c}{ Group } & \multicolumn{1}{c}{ Example of material } \\
\hline 1. Fibers & Tatami & Note \\
2a. Woods (smooth) & Flooring, shelf, etc. & Painted with wax or resin \\
2b. Woods (rough) & Flooring, top board of bay window, etc. & Untreated \\
3. Glasses & Glass table, mirror, etc. & Smooth surface without joint \\
4a. Concretes (smooth) & Tile of bathtub & Rough surface or with joint \\
4b. Concretes (rough) & Tile of bathtub, floor of bathroom & \\
5. Plastics & Cover of toilet bowl, top board of TV, etc. & \\
6. PVCs & Floor of lavatory, floor of bathroom, etc. & \\
7. Metals & Sink, toaster & \\
\hline
\end{tabular}

人の活動等で擾乱されていないことを条件とした。

\section{2. 実験手順}

（1）バックグラウンド（BG）の測定

本論文中での BG とは, 家屋内に扔いて GM 管式サー ベイメータを遮蔽した状態で測定する值，または污染の ない研究室内において GM 管式サーベイメー夕を遮蔽せ ず測定する值を意味する。家屋内では $\mathrm{GM}$ 管式サーベイ メータを鉛ブロック $(50 \mathrm{~mm} \times 100 \mathrm{~mm} \times 200 \mathrm{~mm}) 2$ 個 及びコリメー夕（(株）日本遮蔽技研, EARTHSHIELD ${ }^{\circledR}$ MODEL-E, 側面厚さ $15.9 \mathrm{~mm})$ により遮蔽した。検出 空には $\beta$ カッターまたはスペーサーを取り付けた。 $\beta$ カッ ターとは厚さ $3 \mathrm{~mm}$ のポリプロピレン製のキャップであ り, $\beta$ 線を遮蔽する。スペーサーとは検出器の空が污染 面に接触しないようにするためのリング状のキャップで ある。どちらを付けた場合も対象物から検出空までの距 離は $5 \mathrm{~mm}$ に保たれる。 $\beta$ カッターを付けた場合及びス ペーサーを付けた場合の計数率の差から $\beta$ 線による計数 率を求め, $\mathrm{BG}$ の計算を行った。 $\mathrm{BG}$ 測定では時定数を 30 秒に設定し, 值が安定した後に測定值を 5 回記録した。

\section{(2) 対象部材及びスミアろ紙の測定}

家屋内の部材の測定対象範囲は JIS に則って $100 \mathrm{~cm}^{2}$ $(10 \mathrm{~cm} \times 10 \mathrm{~cm}$ の正方形 $)$ とし，コリメータで遮蔽した GM 管式サーベイメータを用いて正方形の中心を直接法 により測定した。次にスミアろ紙を用いて正方形の枠内 を複数回（10 回程度）拭き取った。拭き取った試料は 污染拡大防止用のチャック付きポリ袋に保存した。最後 に再び同じ場所を直接法により測定した。保存したスミ アろ紙試料は BG の低い茨城県東海村の研究室内におい てコリメータを使用せず GM 管式サーベイメータで測 定した。複数回分の試料のうち, 計数率が $\mathrm{BG}$ 上り有意 に高かった回数のものまでを計算に使用した。対象部材 及びスミアろ紙の測定では時定数を 10 秒に設定し, 值 が安定した後に測定值を 5 回記録した。これらの測定時 も $\mathrm{BG}$ と同様に $\beta$ カッター及びスペーサーを使用した。 $\mathrm{BG}$, 対象部材, 及びスミアろ紙測定時の機材等の構成 を Fig. 2 に示した。

\section{3. 拭き取り荷重}

吉田ら（1964）がタイルを ${ }^{60} \mathrm{Co}$ 硝酸溶液で污染さ せ拭き取る実験を行ったところ, 拭き取り荷重（直 


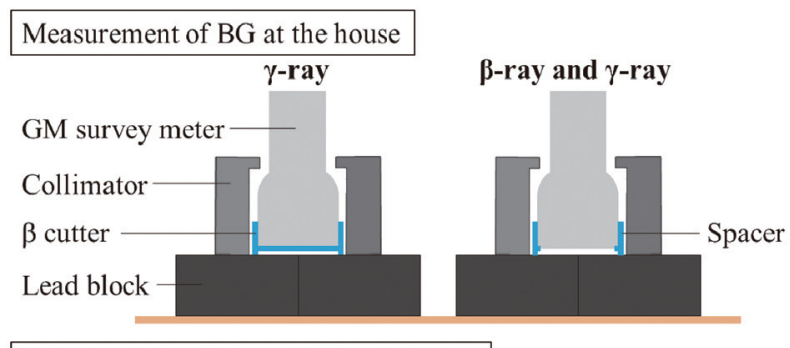

Measurements of materials at the house

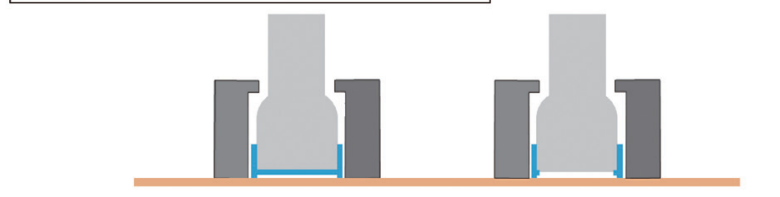

Measurements of BG or smear papers at the laboratory

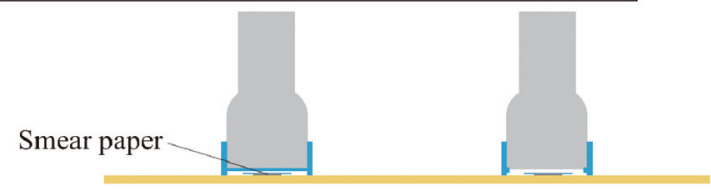

Fig. 2 Configuration on measurements of BG, materials, and smear papers.

径 $25 \mathrm{~mm}$ のスミアろ紙に上から加えられる荷重）が $0.5-1.0 \mathrm{~kg}$ の範囲ではスミアろ紙の測定值が変化しな かった6)。一方で杉浦ら（2007）が汎用ビニル床シート 材であるロンリウムを ${ }^{60} \mathrm{Co}$ 塩酸溶液で污染させ拭き取 る実験を行ったところ, 拭き取り荷重が $1.0 \mathrm{~kg}$ よりさ い場合は拭き取り効率が小さくなったため, 適切な荷重 は 1.0-1.5 kg 程度であるとしている ${ }^{8)}$ 。これらの実験結 果を踏まえ, 本研究では拭き取り荷重を $1 \mathrm{~kg}$ に設定し た。拭き取り荷重を測定する際にはフォースゲージ（(株） イマダ, ZTA-100N）にスミアろ紙を取り付け, 数值を 見ながら拭き取りを行うと同時に，荷重の経時変化を 1 秒あたり 10 回記録した。フォースゲージを用いた拭き 取りの様子を Fig. 3 に示した。本研究における全試料の 拭き取り荷重は $0.99 \pm 0.068 \mathrm{~kg}$ であった。

\section{4. 拭き取り効率及び放射能の計算}

\section{(1) 間接法における拭き取り効率の計算}

間接法では拭き取り効率を用いて表面污染密度を測定 する。遊離性表面污染の表面污染密度 $A_{\mathrm{sr}}\left(\mathrm{Bq} / \mathrm{cm}^{2}\right)$ を 求めるための一般式は次のとおりである。

$$
A_{\mathrm{sr}}=\frac{n-n_{\mathrm{BG}}}{\varepsilon_{\mathrm{i}} \times F \times S \times \varepsilon_{\mathrm{s}}}
$$

ここで $n$ は総計数率 $(\mathrm{cps}), n_{\mathrm{BG}}$ は $\mathrm{BG}$ 計数率 $(\mathrm{cps}), \varepsilon_{\mathrm{i}}$ は $\beta$ 粒子に対する機器効率, $F$ は拭き取り効率, $S$ は拭

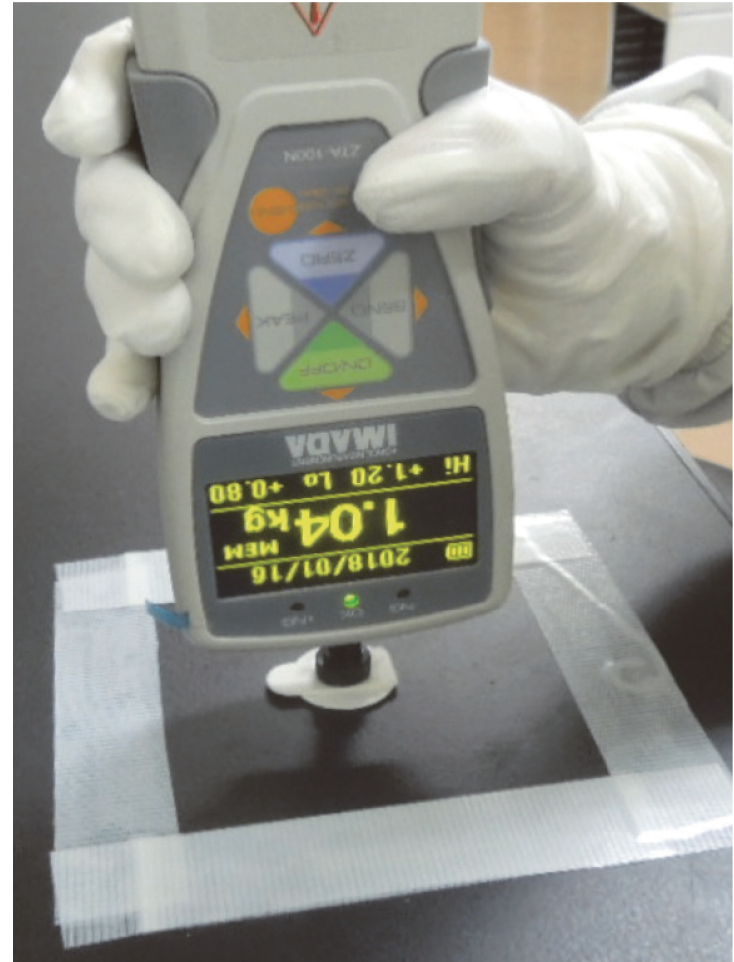

Fig. 3 Wipes with the force gauge. Wipe force is approximately $1 \mathrm{~kg}$.

き取り面積 $\left(\mathrm{cm}^{2}\right), \varepsilon_{\mathrm{s}}$ は放射性表面污染の線源効率であ る。本研究では上記の式内の拭き取り効率 $F$ の実験的 評価值を得るため複数回の拭き取りを行った。拭き取り 効率 F は次の式で与えられる。

$$
F=A_{1} / A_{\mathrm{r}}
$$

ここで, $A_{1}$ は 1 回の拭き取りで拭き取った放射能 $(\mathrm{Bq})$, $A_{\mathrm{r}}$ は拭き取りを行う前に存在した遊離性表面污染の放 射能 $(\mathrm{Bq})$ である。 $A_{\mathrm{r}}$ は複数回の拭き取り試験で拭き取っ た放射能を合算することにより精度よく推定することが できる5 。よって本研究では $A_{\mathrm{r}}$ を次の式のように定義す る。

$$
A_{\mathrm{r}}=\sum_{i=1}^{N} A_{i}
$$

ここで, $N$ は拭き取り回数, $A_{i}$ は $i$ 回目の拭き取りで拭 き取った放射能 $(\mathrm{Bq})$ である。 $A_{i}$ は次の式を用いて計 算した。

$$
A_{i}=\frac{\left(\overline{n_{i, \beta \gamma}}-\overline{n_{\mathrm{BG}, \beta \gamma}}\right)\left(\overline{n_{i, \gamma}}-\overline{n_{\mathrm{BG}, \gamma}}\right)}{\varepsilon_{\mathrm{i}} \times \varepsilon_{\mathrm{s}} \times C}
$$

ここで， $\overline{n_{i, \beta \gamma}}$ はスペーサーを付けて測定した $i$ 回目のス ミアろ紙サンプルの計数率の平均值 $(\mathrm{cps}), \overline{n_{\mathrm{BG}, \beta \gamma}}$ はスペー 
サーを付けて測定した BG 計数率の平均值 $(\mathrm{cps}), \overline{n_{i, \gamma}}$ は $\beta$ カッターを付けて測定した $i$ 回目のスミアろ紙サンプ ルの計数率の平均值 (cps), $\overline{n_{\mathrm{BG}, \gamma}}$ は $\beta$ カッターを付けて 測定した $\mathrm{BG}$ 計数率の平均值（cps），Cはろ紙を挟んだ ポリ袋の遮蔽係数である。本研究において, 遮蔽係数 $C$ は 0.85 であった。機器効率 $\varepsilon_{\mathrm{i}}$ は $\beta$ 線の最大エネルギー や線源と検出器との幾何条件により異なる。線源効率 $\varepsilon_{\mathrm{s}}$ は測定対象の材質により異なる。本研究で使用したサー ベイメータはアルミニウムプレート製の ${ }^{36} \mathrm{Cl}$ を線源とし 線源と検出空を $5 \mathrm{~mm}$ 離した位置で校正を行い, 計数率 から放射能への換算係数を決定している。污染の主な核 種である ${ }^{137} \mathrm{Cs}$ 及び ${ }^{134} \mathrm{Cs}$ の $\beta$ 線エネルギーの範囲では機 器効率に違いはなく ${ }^{10)}$, ほとんどの部材がアルミニウム プレートと同様の線源効率（0.6）であった ${ }^{11)}$ ため, サー ベイメータに記載の換算係数 $\left(7.4 \times 10^{-2} \mathrm{~Bq} / \mathrm{min}^{-1}\right)$ を用 いて放射能の計算を行った。木材の線源効率は 0.5 であ $り^{11)}$, 畳の線源効率は明らかでないため JIS に従い 0.5 としたため，畳及び木材類の測定時は換算係数に 0.6/0.5 を掛けて補正した。それ以外の部材やスミアろ紙の場合 は線源効率に 0.6 を用いた。

\section{(2) 直接法による表面污染密度の計算}

直接法では遊離性表面污染だけでなく固定性表面污染 も測定している。本研究では, 拭き取り前に直接法で測 定した放射能を全表面污染の放射能 $A_{\mathrm{t}}(\mathrm{Bq})$, 拭き取り 後に直接法で測定した放射能を固定性表面污染の放射能 $A_{\mathrm{f}}(\mathrm{Bq})$ とみなし, 次のように定義する。

$$
A_{\mathrm{t}}=A_{\mathrm{r}}+A_{\mathrm{f}}
$$

全表面污染の表面污染密度 $A_{\mathrm{st}}\left(\mathrm{Bq} / \mathrm{cm}^{2}\right)$ は次の式によ り計算した。

$$
A_{\mathrm{st}}=\frac{\left(\overline{n_{\mathrm{bfr}, \beta \gamma}}-\overline{n_{\mathrm{BG}, \beta \gamma}}\right)\left(\overline{n_{\mathrm{bfr}, \gamma}}-\overline{n_{\mathrm{BG}, \gamma}}\right)}{\varepsilon_{\mathrm{i}} \times W \times \varepsilon_{\mathrm{s}}}
$$

ここで， $\overline{n_{\mathrm{bfr}, \beta \gamma}}$ は拭き取り前にスペーサーを付けて直接 法により測定した計数率の平均值 $(\mathrm{cps}), \overline{n_{\mathrm{bfr}, \gamma}}$ は拭き取 り前に $\beta$ カッターを付けて直接法により測定した計数率 の平均值 $(\mathrm{cps}), W$ は $\mathrm{GM}$ 管式サーベイメータの有効空 面積 $\left(\mathrm{cm}^{2}\right)$ である。本研究において $W$ は $19.6 \mathrm{~cm}^{2}$ であっ た。また, 固定性表面污染の表面污染密度 $A_{\mathrm{sf}}\left(\mathrm{Bq} / \mathrm{cm}^{2}\right)$ は次の式で与えられる。

$$
A_{\mathrm{sf}}=\frac{\left(\overline{n_{\mathrm{aft}, \beta \gamma}}-\overline{n_{\mathrm{BG}, \beta \gamma}}\right)\left(\overline{n_{\mathrm{aft}, \gamma}}-\overline{n_{\mathrm{BG}, \gamma}}\right)}{\varepsilon_{\mathrm{i}} \times W \times \varepsilon_{\mathrm{s}}}
$$

ここで, $\overline{n_{\mathrm{aft}, \beta \gamma}}$ は拭き取り後にスペーサーを付けて直接
法により測定した計数率の平均值 $(\mathrm{cps}), \overline{n_{\mathrm{aft}, \gamma}}$ は拭き取 り後に $\beta$ カッターを付けて直接法により測定した計数率 の平均值（cps）である。

(3) 検出限界の計算

(4) 式, (6) 式, 及び (7) 式の計算を行う際には, スペー サーまたは $\beta$ カッターを付けて測定した各サンプルの計 数率が検出限界の計数率を上回っていることを確認する 必要がある。検出限界の計数率 $n_{\mathrm{d}, p}(\mathrm{cps})$ は次の式で計 算した ${ }^{12)}$ 。スペーサーを付けた場合は $p=\beta \gamma, \beta$ カッター を付けた場合は $p=\gamma$ となる。

$$
n_{\mathrm{d}, p}=\frac{K}{2}\left\{\frac{K}{2 \tau_{\mathrm{s}} m}+\sqrt{\left(\frac{K}{2 \tau_{\mathrm{s}} m}\right)^{2}+2 \overline{n_{\mathrm{BG}, p}}\left(\frac{1}{\tau_{\mathrm{s}} m}+\frac{1}{\tau_{\mathrm{BG}} m}\right)}\right\}
$$

ここで, $K$ は標準偏差の倍数, $\tau_{\mathrm{s}}$ はサンプル測定時の時 定数 $(\mathrm{s}), m$ は測定回数, $\tau_{\mathrm{BG}}$ は $\mathrm{BG}$ 測定時の時定数 $(\mathrm{s})$ である。 $K$ は一般的に 3 を用いる。本研究においては, $\tau_{\mathrm{S}}$ は $10 \mathrm{~s}, m$ は 5 回, $\tau_{\mathrm{BG}}$ は $30 \mathrm{~s}$ とした。

\section{III 結 果 と 考 察}

\section{1. 拭き取り効率}

本試験の結果で示したすべての誤差には, サーベイ メータの 5 回の読み取り值による計数率のばらつき, 及 び同一分類中における複数の異なる部材がもつそれぞれ の拭き取り効率のばらつきが含まれている。本研究では, 計数率のばらつき, 各部材の拭き取り効率のばらつき, そしてそれらを合成した一分類としてのばらつきをすべ て正規分布と仮定し，平均值と標準偏差を計算した。

各部材の拭き取り効率の結果を Fig. 4 に示す。拭き 取り効率が最も高かった部材は 3. ガラス類及び 4 a. コ ンクリート類 (平滑) で，それぞれ $79 \% \pm 7.7 \%$ 及び

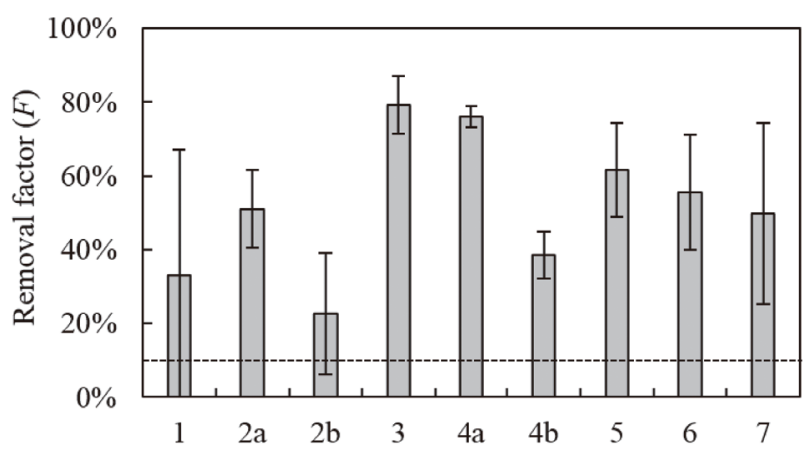

Fig. 4 Removal factor $(F)$ of each material. 1: fibers, 2a: woods (smooth), 2b: woods (rough), 3: glasses, 4a: concretes (smooth), 4b: concretes (rough), 5: plastics, 6: PVCs and 7: metals. Dotted line means removal factor of $10 \%$. 
$76 \% \pm 2.9 \%$ であった。最も低かった部材は $2 \mathrm{~b}$. 木材類 （凹凸）の $23 \% \pm 16 \%$ であったが，部材により拭き取り 効率が大きく異なっており, 最も低いものは $9.5 \%$, 最 も高いもので $53 \%$ であった。2a. 木材類（平滑）の拭き 取り効率は $51 \% \pm 11 \%$ であり, 木材表面に塗装等の処 理が施してある場合は，表面が未処理のものと比較して 拭き取り効率が高くなった。同様に，4a. コンクリート (平滑) の拭き取り効率は $4 \mathrm{~b}$. コンクリート（凹凸）の 2 倍程度であり, 表面状態及び目地の有無により大きく 異なっていた。1. 繊維類に分類した鳁は拭き取り効率の 誤差が非常に大きかった。これは主に計数率のばらつき が原因であると考えられる。畳はスミアろ紙により拭き 取れた污染が ND-0.05 Bq $/ \mathrm{cm}^{2}$ と非常に少なかったため, 各スミアろ紙の表面污染密度を求める計算過程におい て，その誤差が相対的に大きくなったと考えられる。

本研究で調查した部材の中で拭き取り効率が $10 \%$ 未 満となったのは $2 \mathrm{~b}$. 木材類（凹凸）の中の一つの部材の みであり, それ以外の部材では $10 \%$ を大きく上回って いた。また先行研究においても, 污染源や拭き取り荷重 に関わらず $10 \%$ より高い值であった ${ }^{6-9)}$ 。よって拭き取 り効率が不明な部材に対して $10 \%$ を適用することは表 面污染密度を過大評価する可能性が高いため, 污染の評 価という観点では適切ではないことがわかった。

\section{2. 固定性表面污染の割合}

拭き取り効率は遊離性表面污染のうち 1 回目で拭き取 ることができた污染の割合であるため, 間接法を用いて 測定できるのは遊離性表面污染の放射能のみである。家 屋内污染による外部被ばくを評価するためには固定性表 面污染の割合についてもどの程度であるかを知る必要 がある。（6）式及び（7）式から求めた各部材の固定性 表面污染の割合を Fig. 5 に示す。固定性表面污染の割合 が最も低かったのは 3. ガラス類及び 5. プラスチック類 で，それぞれ $14 \% \pm 11 \%$ 及び $15 \% \pm 12 \%$ であった。一 方最も高かったのは 1. 瀻維類の $101 \% \pm 16 \%$ であった。 その要因として, 畳の繊維の隙間に污染が入り込み, 複 数回の拭き取りにもかかわらず污染はほとんど拭き取 れていなかったことが考えられる。畳は拭き取れた污 染が非常に少なかったため拭き取り前後で表面污染に変 化がなかった。よって計数率誤差の影響を受けて固定性 表面污染の割合が $100 \%$ を超える場合があった。2a. 木 材類（平滑）では $65 \% \pm 15 \%, 2 \mathrm{~b}$. 木材類（凹凸）では $81 \% \pm 9.7 \%$ となったことから, 表面が未処理の木材は 遊離性表面污染の割合が少なく，かつその遊離性表面污

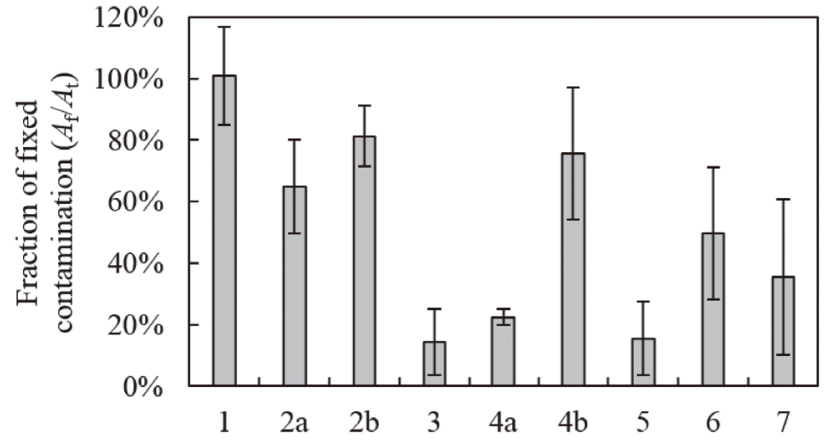

Fig. 5 Fraction of fixed contamination $\left(A_{\mathrm{f}} / A_{\mathrm{t}}\right)$ of each material. 1: fibers, 2a: woods (smooth), 2b: woods (rough), 3: glasses, 4a: concretes (smooth), 4b: concretes (rough), 5: plastics, 6: PVCs and 7: metals.

染も一度で拭き取ることは困難であることがわかった。 4a. コンクリート類 (平滑) は $22 \% \pm 2.5 \%, 4 \mathrm{~b}$. コンクリー 卜類（凹凸）は $76 \% \pm 21 \%$ となり，污染の大部分は凹 凸部及び目地の部分に固定されていると考えられる。本 研究では畳の污染がほとんど拭き取れて抒らず，拭き取 り効率を正確に算出できていない可能性があることがわ かった。よってこれ以降は畳を除いた結果を議論してい くこととする。

\section{3. 污染の回収率}

（5）式に示したと抢り, 理論上は $A_{\mathrm{r}}$ と $A_{\mathrm{f}}$ の和が $A_{\mathrm{t}}$ と なる。ここでは, 拭き取り前に直接法で測定した放射 能 $\left(A_{\mathrm{t}}\right)$ に対して, 複数回の拭き取りによって拭き取っ た放射能の合計 $\left(A_{\mathrm{r}}\right)$ と拭き取り後に直接法で測定した 放射能 $\left(A_{\mathrm{f}}\right)$ との和がどの程度の割合であったかを污染 の回収率と呼ぶこととし, 計算を行った。Fig. 6 に, 各 部材の污染の回収率を示した。污染の回収率は最も低い

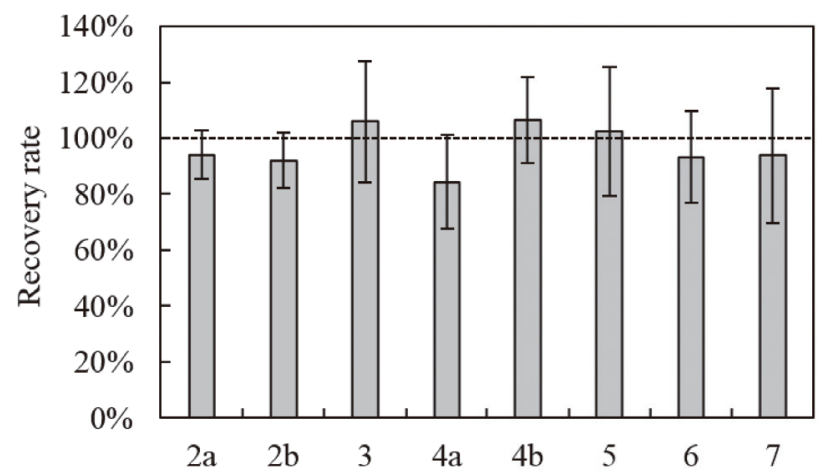

Fig. 6 Recovery rate of contamination. 2a: woods (smooth), 2b: woods (rough), 3: glasses, 4a: concretes (smooth), 4b: concretes (rough), 5: plastics, 6: PVCs and 7: metals. Dotted line means recovery rate of $100 \%$. 
もので $84 \% \pm 17 \%$, 最も高いもので $106 \% \pm 22 \%$ となり, すべての分類で $100 \%$ から大きく外れることはなかっ た。污染の回収率が $100 \%$ にならなかった原因として考 えられるのは，拭き取り範囲の污染の不均一性，及び拭 き取り行為によるサーベイメータ検出範囲内への污染の 流入または範囲外への污染の流出である。これらの影響 を調べるためには，拭き取り前後の部材に付着している 污染の分布をイメージングプレート等により把握してお く必要がある。污染の回収率は, 同一の部材上の複数個 所における直接法による測定や，直接法の測定範囲と 間接法の拭き取り範囲を統一するといった方法により, 100\%に近づけることができると考えられる。

\section{4. 表面污染密度}

本研究において直接法で測定した拭き取り前の全表面 污染密度の範囲は 0.49-10 Bq/ $\mathrm{cm}^{2}$ ，中央值は $3.0 \mathrm{~Bq} / \mathrm{cm}^{2}$ であった。Fig. 7 に全表面污染密度と拭き取り効率との 関係を示す。各部材の測定值を含む範囲に影を付けた。 7. 金属類を除いた部材では拭き取り効率は全表面污染密 度の影響を受けていないと考えられる。金属類について は污染レベルが低い場合に拭き取り效率が高く污染レベ ルが高い場合に拭き取り効率が低いように見えるが，污 染レベルの高い 2 点では全表面污染密度が 2 倍以上異な る $\left(4.1 \mathrm{~Bq} / \mathrm{cm}^{2}\right.$ 及び $\left.9.3 \mathrm{~Bq} / \mathrm{cm}^{2}\right)$ ものの拭き取り効率の 差はわずか $(28 \%$ 及び $23 \%)$ であり，拭き取り効率と

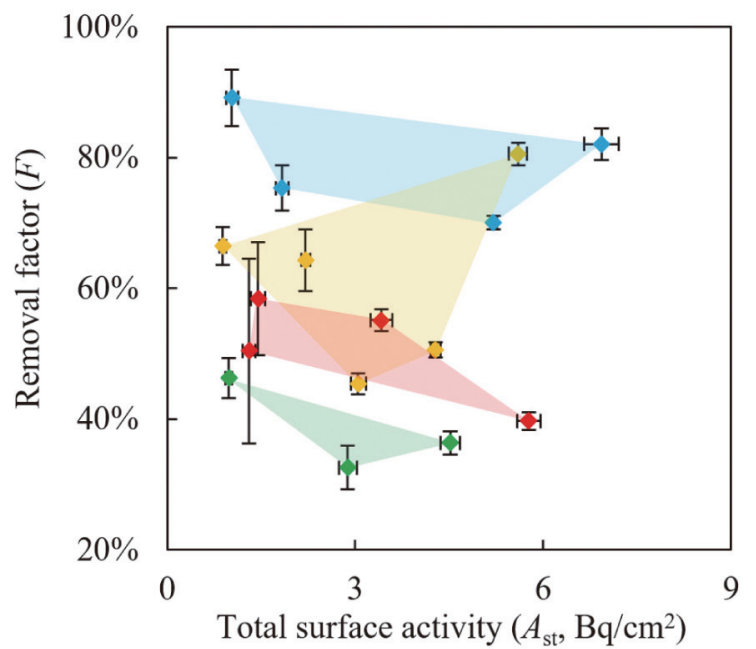

- 2a. Woods (smooth) $\quad 3$. Glasses

$\bullet 4 \mathrm{~b}$. Concretes (rough) $\bullet 5$. Plastics
全表面污染密度との間に明確な相関があると判断する ことは難しい。杉浦ら（2007）では，表面污染密度が 0.05-50 Bq/ $\mathrm{cm}^{2}$ の範囲に打いては拭き取り荷重が一定で あれば污染の大小により拭き取り効率は変化しないと述 べられており ${ }^{8}$ ，本研究もこれに矛盾しない結果となっ た。

\section{5. 拭き取り効率と固定性表面污染の割合との関係}

拭き取り効率 $F$ と固定性表面污染の割合 $A_{\mathrm{f}} / A_{\mathrm{t}}$ との関 係を Fig. 8 に示した。拭き取り効率 $F$ と固定性表面污染 の割合 $A_{\mathrm{f}} / A_{\mathrm{t}}$ には負の相関があった。これは遊離性表面 污染 $A_{\mathrm{r}}$ が少ない部材ほど 1 回目の拭き取りで取り除け る污染が少ないことを示している。ここで，本研究によ り求められた関係を用いて，全表面污染 $A_{\mathrm{t}}$ に対して 1 回目の拭き取りで取り除ける污染の割合（以下，污染除 去率 $D$ と呼ぶ）について考察する。

遊離性表面污染の割合 $A_{\mathrm{r}} / A_{\mathrm{t}}$ を $1-A_{\mathrm{f}} / A_{\mathrm{t}}$ で表せると仮 定すると, 污染除去率 $D$ は

$$
D=\left(1-A_{\mathrm{f}} / A_{\mathrm{t}}\right) \times F
$$

で表される。また，拭き取り効率 $F$ と固定性表面污染 の割合 $A_{\mathrm{f}} / A_{\mathrm{t}}$ が比例関係であるとすると, a 及び $\mathrm{b}$ を定 数とした関数

$$
A_{\mathrm{f}} / A_{\mathrm{t}}=\mathrm{a} F+\mathrm{b}
$$

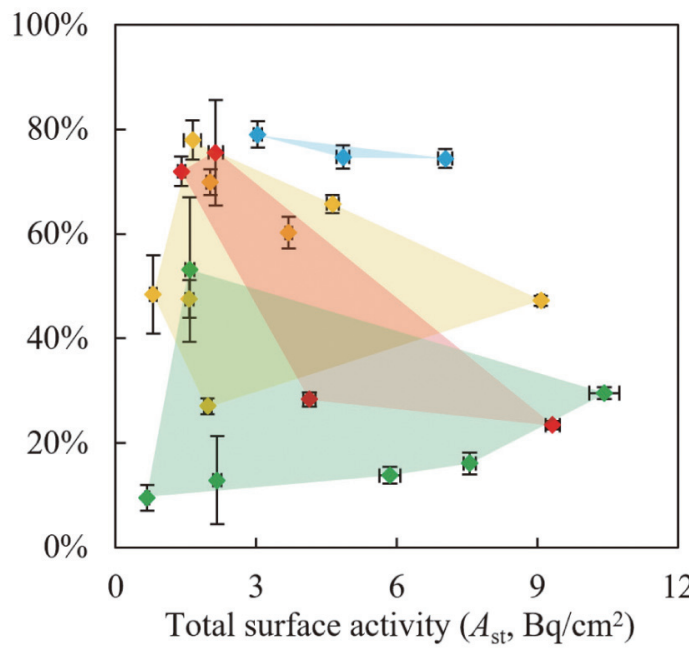

- 2b. Woods (rough) 4 a. Concretes (smooth) 6. PVCs 7. Metals

Fig. 7 Relationship between total surface activity $\left(A_{t}\right)$ and removal factor $(F)$. 2a: woods (smooth), 3: glasses, 4b: concretes (rough), 5: plastics are in the left figure, and 2b: woods (rough), 4a: concretes (smooth), 6: PVCs and 7: metals are in the right figure. The range which contains the measurement data of each material was colored. 


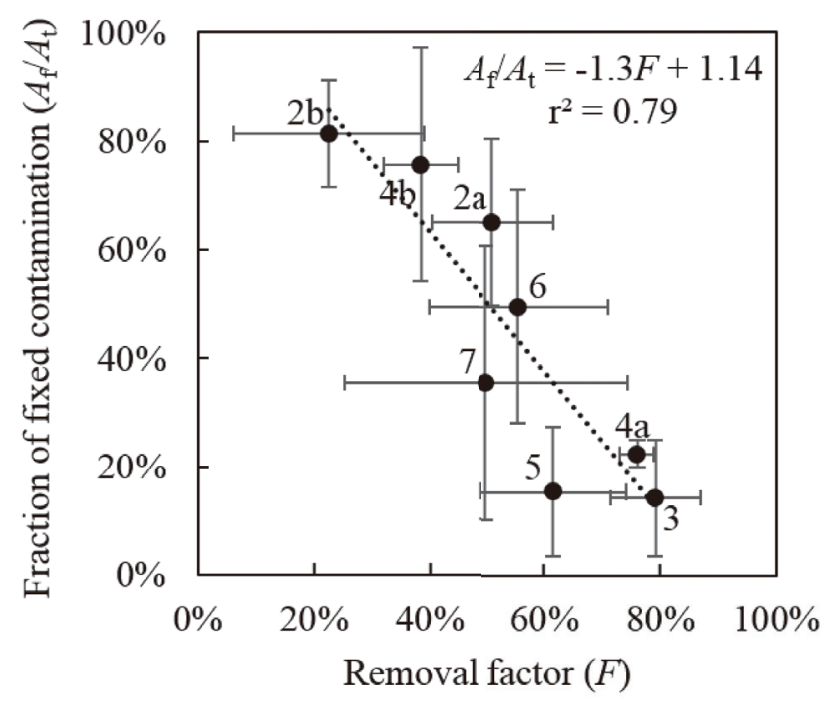

Fig. 8 Relationship between removal factor $(F)$ and fraction of fixed contamination $\left(A_{\mathrm{f}} / A_{\mathrm{t}}\right)$. 2a: woods (smooth), 2b: woods (rough), 3: glasses, 4a: concretes (smooth), 4b: concretes (rough), 5: plastics, 6: PVCs and 7: metals.

と（9）式から, 污染除去率 $D$ は

$$
D=\mathrm{a} F^{2}+(1-\mathrm{b}) F
$$

となる。本研究の結果から求めた拭き取り効率と污染除 去率との関係を Fig. 9 に示す。図中の曲線は（11）式よ り求めた二次関数のグラフである。最大 $25 \%$ 程度の誤 差はあるが，全体として本研究の結果もこの式を否定し ないものであった。このように, 拭き取り効率が低いほ ど実際に拭き取れる污染の割合は加速度的に小さくなる 可能性が示唆された。

\section{6. 表面污染密度の評価手法の違いが室内空間線量率}

\section{に及ぼす影響}

（国研）日本原子力研究開発機構が 2012 年 12 月に調 查を行った大熊町の家屋のうち最も污染レベルが高かっ た家屋に扔ける床及び壁の計数率をもとに, 本研究で 求めた污染除去率を用いて床及び壁の表面污染密度を 評価した。評価された表面污染密度の中央值（Table 2) を利用して, 家屋内の高さ $1 \mathrm{~m}$ に抢ける空間線量率を シミュレーションにより計算した。計算には PHITS2 ${ }^{13)}$ （Ver. 2.880）を用い, 対象核種は ${ }^{137} \mathrm{Cs}$ 及び ${ }^{134} \mathrm{Cs}$ とし た。計算体系を Fig. 10 に示す。想定した家屋の大きさ は $72 \mathrm{~m}^{2}$, 天井高は $2.4 \mathrm{~m}$ とした。主な滞在場所となる 3 つの部屋 (それぞれ $12 \mathrm{~m}^{2}, 16 \mathrm{~m}^{2}, 20 \mathrm{~m}^{2}$ ) の高さ $1 \mathrm{~m}$ の地点に抢ける空間線量率を $25 \mathrm{~cm} \times 25 \mathrm{~cm}$ のメッシュ 毎に計算した。10\%の拭き取り効率を用いて表面污染

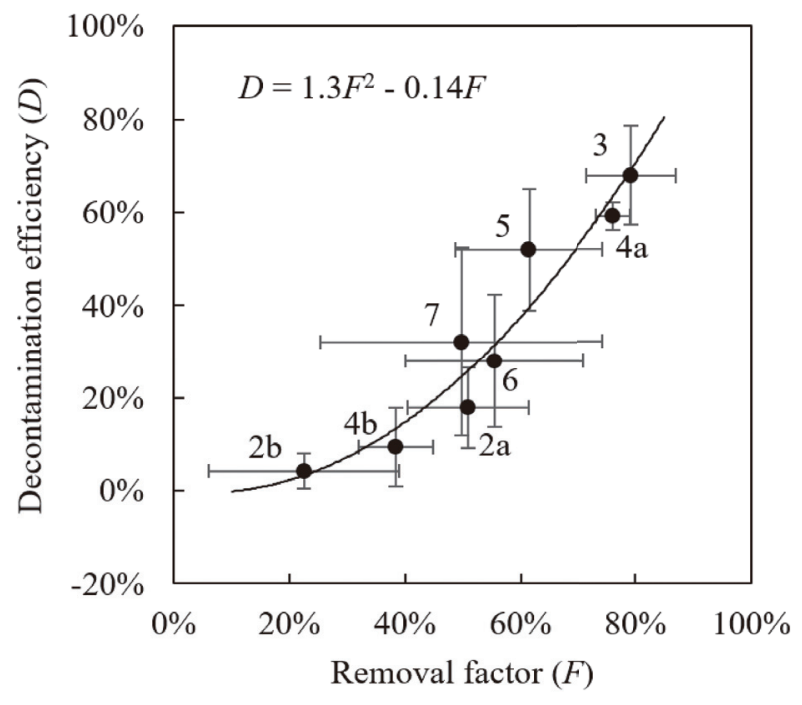

Fig. 9 Relationship between removal factor $(F)$ and decontamination efficiency $(D)$. 2a: woods (smooth), 2b: woods (rough), 3: glasses, 4a: concretes (smooth), 4b: concretes (rough), 5: plastics, 6: PVCs and 7: metals. Black line indicates a theoretical formula of relationship between removal factor $(F)$ and decontamination efficiency $(D)$ assuming that removal factor $(F)$ and fraction of fixed contamination $\left(A_{\mathrm{f}} / A_{\mathrm{t}}\right)$ are in proportion.

Table 2 Median of the assessed surface contamination inside house in Okuma Town $\left(\mathrm{Bq} / \mathrm{cm}^{2}\right)$. Case 1 and Case 2 mean the surface contamination calculated by using decontamination efficiency and $10 \%$ removal factor, respectively.

\begin{tabular}{cccc}
\hline & Number of samples & Case $1\left(\mathrm{~Bq} / \mathrm{cm}^{2}\right)$ & Case $2\left(\mathrm{~Bq} / \mathrm{cm}^{2}\right)$ \\
\hline Floor & 76 & 4.2 & 7.5 \\
Wall & 38 & 0.069 & 0.16 \\
\hline
\end{tabular}

密度を評価した場合についても同様に計算し, 空間線量 率を比較した。家屋内の空間線量率の分布を Fig. 11 に, 各部屋に打ける空間線量率を Table 3 に示す。家屋内污 染に由来する空間線量率は, 污染除去率を用いて評価し た場合（ケース 1）で 0.029-0.068（算術平均值 0.053） $\mu \mathrm{Sv} / \mathrm{h}, 10 \%$ の拭き取り効率を用いて評価した場合（ケー ス 2）で 0.052-0.124（算術平均值 0.096） $\mu \mathrm{Sv} / \mathrm{h}$ となり, ケース 2 の方が 2 倍程度高かった。污染除去率を用いて 計算した各部屋の空間線量率は, 部屋 1 で $0.050 \mu \mathrm{Sv} / \mathrm{h}$, 部屋 2 で $0.053 \mu \mathrm{Sv} / \mathrm{h}$, 部屋 3 で $0.054 \mu \mathrm{Sv} / \mathrm{h}$ となり, 部 屋の床面積が大きいほどわずかに高くなる傾向があっ た。家屋内の污染に由来する空間線量率は, 2012 年 12 月当時の屋外の空間線量率の算術平均值である $4.9 \mu \mathrm{Sv} /$ $\mathrm{h}^{14)}$ の約 $1 \%$ であり, 外部被ばく線量に与える家屋内污 染の影響が非常に小さいことがわかった。 


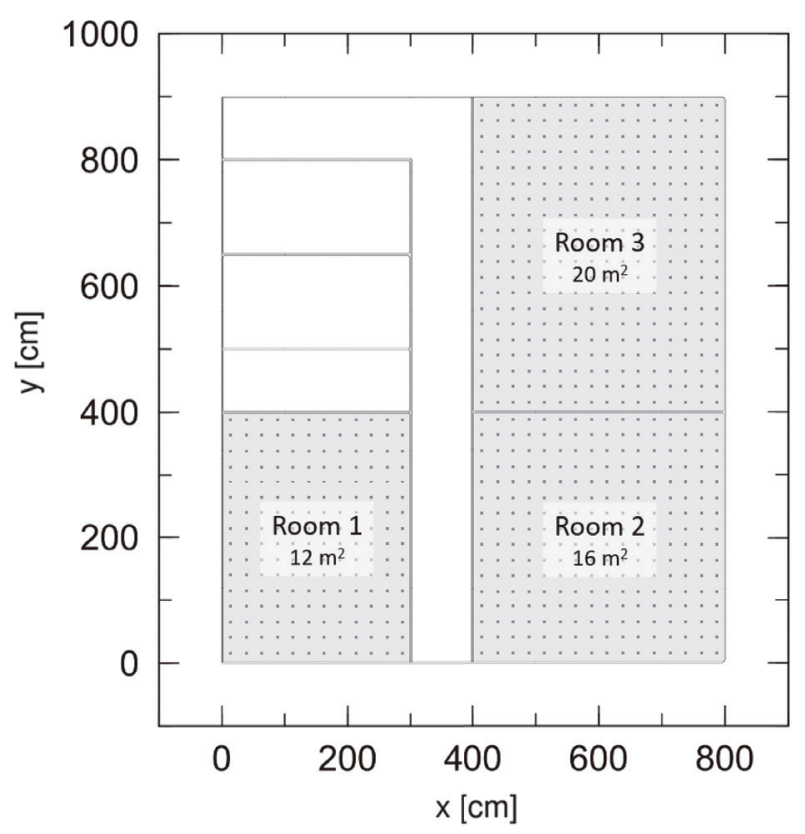

Fig. 10 Layout of the house which simulated air dose rate. Air dose rates were calculated for every mesh of $25 \mathrm{~cm} \times 25 \mathrm{~cm}$ at $1 \mathrm{~m}$ height in room $1\left(12 \mathrm{~m}^{2}\right)$, room 2 $\left(16 \mathrm{~m}^{2}\right)$, and room $3\left(20 \mathrm{~m}^{2}\right)$. Dots indicate measurement points.

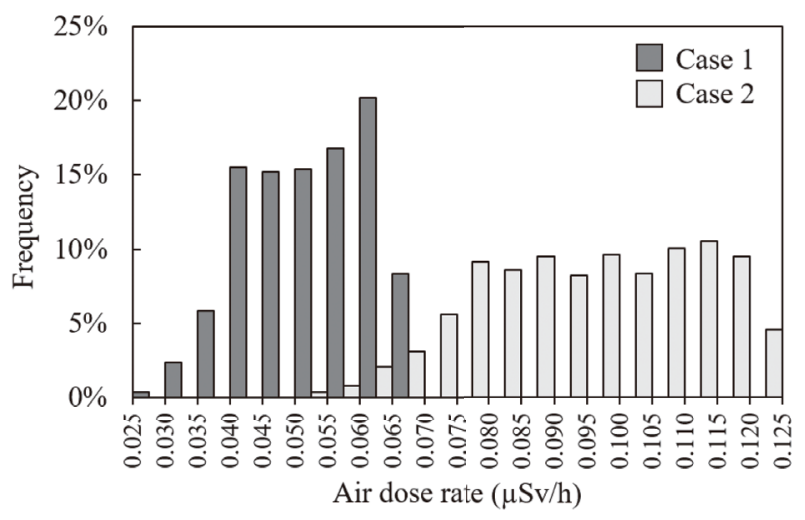

Fig. 11 Distribution of air dose rate $(\mu \mathrm{Sv} / \mathrm{h})$ inside house at $1 \mathrm{~m}$ height. Case 1 and Case 2 mean the air dose rate calculated by using decontamination efficiency and 10\% removal factor, respectively.

Table 3 Average of air dose rate of each room $(\mu \mathrm{Sv} / \mathrm{h})$. Case 1 and Case 2 mean the air dose rate calculated by using decontamination efficiency and $10 \%$ removal factor, respectively.

\begin{tabular}{cccc}
\hline & Floor area $\left(\mathrm{m}^{2}\right)$ & Case $1(\mu \mathrm{Sv} / \mathrm{h})$ & Case $2(\mu \mathrm{Sv} / \mathrm{h})$ \\
\hline Room 1 & 12 & $0.050 \pm 0.0088$ & $0.091 \pm 0.016$ \\
Room 2 & 16 & $0.053 \pm 0.0091$ & $0.096 \pm 0.016$ \\
Room 3 & 20 & $0.054 \pm 0.0092$ & $0.098 \pm 0.017$ \\
\hline
\end{tabular}

IV 結 論

原子力事故後において家屋内に浸入した污染に由来す る被ばく線量を正確に評価するため, 大熊町, 双葉町, 及び浪江町の実家屋においてさまざまな家屋内装部材の 拭き取り効率を調査した。その結果, 畳を除くすべての 部材で拭き取り効率が $10 \%$ を上回った。拭き取り効率 と固定性表面污染の割合には負の相関があり，これによ り拭き取り効率と污染除去率の関係が二次関数である可 能性が示唆された。実験により得られた污染除去率及び JIS に記載された $10 \%$ の拭き取り効率を用いて家屋内污 染に由来する空間線量率を計算した結果， $10 \%$ の拭き 取り効率を用いた場合は污染除去率を用いた場合と比 較して空間線量率の計算結果が 2 倍程度高かった。污染 除去率を用いた場合の空間線量率は屋外の空間線量率の 約 $1 \%$ にあたる $0.05 \mu \mathrm{Sv} / \mathrm{h}$ 程度となり, 外部被ばく線量 に与える家屋内污染の影響が非常に小さいことがわかっ た。

\section{$V$ 今後の課 題}

州還困難区域への立ち入り時間に制限があること, 調 査可能な家屋が限られていることなどにより, 本研究に おける調査は各分類について 3 種類から 8 種類にとど まった。拭き取り効率及び污染除去率の変化の範囲がど の程度であるかを議論するためには, 同様の実験を繰り 返し多くのデー夕を集積すること，及び条件を一定にし た実験室実験を行うことが必要である。また污染の回収 率は固定性表面污染の割合に影響を与えるため, 回収率 が 100\% とならない原因を明らかにする必要がある。こ れには拭き取り前後の污染分布をイメージングプレート により把握することが有効であると考えられる。これら の課題を解決するため, 今後は実験室において一定の部 材や污染源を用いた体系的な実験を行い, 拭き取り効率 等に影響する要因を明らかにしていく。

\section{謝辞}

本研究の調査にご協力いただき, ご自宅を提供してく ださいました大熊町, 双葉町, 及び浪江町の家屋所有者 の皆様に感謝申し上げます。

\section{利益相反の開示}

本研究の実施及び論文の執筆に関し，著者らが開示す べき利益相反関係にある企業等はありません。 


\section{参 考 文 献}

1) Ministry of Economy, Trade and Industry; Areas to which evacuation orders have been issued (April 1, 2017) (2017). Available at: http://www.meti.go.jp/earthquake/nuclear/ kinkyu/hinanshiji/2017/pdf/0401gainenzu.pdf, Accessed 19 July, 2018 (in Japanese).

2) Nuclear Emergency Response Headquarters; Basic Concept and Issues to be Challenged for Rearranging the Restricted Areas and Areas to which Evacuation Orders Have been Issued where Step 2 has been Completed (2011). Available at: http://www.meti.go.jp/english/ earthquake/nuclear/roadmap/pdf/20111226_01.pdf, Accessed 19 July 2018.

3) Ministry of the Environment; Progress on Decontamination \& Interim Storage Facility (2014). Available at: http://www. mofa.go.jp/files/000051402.pdf, Accessed 19 July 2018.

4) H. Yoshida-Ohuchi, T. Kanagami, Y. Satoh, M. Hosoda, Y. NaitoH and M. KameYama; Indoor radiocaesium contamination in residential houses within evacuation areas after the Fukushima nuclear accident. Sci. Rep., 6, Article number: 26412 (2016).

5) Japanese Industrial Standards Committee; Evaluation of surface contamination Beta-emitters (maximum beta energy greater than $0.15 \mathrm{MeV}$ ) and alpha-emitters. JIS Z 4504 (2008) (in Japanese).

6) Y. Yoshida, Y. Sasaki, M. Murata, S. Izawa and Y. IkEZAWA; Experiment study of smear survey. J. At. Energy Soc. Jpn., 6, 77-81 (1964) (in Japanese).

7) G. W. Royster and B. R. Fish; Techniques for assessing "removable" surface contamination, B. R. Fish (ed.) “Surface Contamination”, pp. 201-207 (1964), Pergamon
Press, Oxford.

8) N. Sugiura, J. Taira, K. TakenaKa, K. YamanaKa, K. SugaI and T. KosaKo; Experimental analysis on removal factor of smear method in measurement of surface contamination. Jpn. J. Health Phys., 42, 214-220 (2007) (in Japanese).

9) T. IChiJ and H. OGINO; Experimental evaluation of removal factor in smear method for surveying radioactive surface contamination of transport cask. Jpn. J. Health Phys., 46, 52-59 (2011) (in Japanese).

10) Japanese Industrial Standards Committee; Portable radiation surface contamination meters and monitors. JIS Z 4329 (2004) (in Japanese).

11) T. ICHiJ and H. Ogino; Experimental study on source efficiencies of various materials contaminated with radioactivity. Trans. At. Energy Soc. Jpn., 6, 370-375 (2007) (in Japanese).

12) M. Kishida and S. Suga; Radiation Monitoring of the Workplace (XI): Air Monitoring (7) Measurement of Samples, Jpn. Radioisotope Assoc. (ed.) "Sagyoukankyou no Housyasen Monitaringu -Keikaku Ritsuan kara Hyouka made-" [Radiation Monitoring of the Workplace -from planning to assessment], 99-110 (1978) (in Japanese).

13) T. Sato, K. Nitta, N. Matsuda, S. Hashimoto, Y. Iwamoto, et al.; Particle and Heavy Ion Transport Code System PHITS, Version 2.52. J. Nucl. Sci. Technol., 50, 913-923 (2013).

14) Nuclear Regulation Authority; Readings of air dose in the $20 \mathrm{~km}$ zone of Fukushima Dai-ichi NPP (December 2012) (2012). Available at: http://radioactivity.nsr.go.jp/en/ list/239/list-201212.html, Accessed 19 July 2018. 